\title{
HUMAN RIGHTS AND THE WTO: ISSUES FOR THE PACIFIC
}

\author{
Sarah Joseph*
}

In the Pacific, Australia, New Zealand, Fiji, Papua New Guinea, Solomon Islands and Tonga are World Trade Organization members. This article examines the human rights concerns regarding the WTO, in particular the impact of WTO rules regarding trade liberalisation on poverty and development within developing states. The author comments on the costs of conditional WTO membership and the possible consequences of free trade and globalisation in the Pacific region.

\section{INTRODUCTION}

The World Trade Organization (WTO) was created in 1994 after the conclusion of the Uruguay round of negotiations under the General Agreement of Tariffs and Trade (GATT) by the Marrakesh Agreement establishing the World Trade Organization. ${ }^{1}$ The GATT was transformed into a powerful international institution, the WTO. The WTO supervises the implementation of international rules on trade liberalisation, and also serves as a negotiating forum for further liberalisation. Its mandate extends beyond that of the GATT into areas such as liberalisation of trade in services as well as the protection of intellectual property rights.

In the Pacific, Australia, New Zealand, Fiji, New Zealand, Papua New Guinea, Solomon Islands, and, as of 2007, Tonga, are WTO members. The current members, apart from Tonga, were so at the time of the transformation of the GATT into the WTO. Samoa and Vanuatu have observer status. Timor Leste, Nauru, Tuvalu, Palau, Kiribati, Micronesia, and the Marshall Islands currently have no official relationship with the WTO.

The theory of comparative advantage provides the theoretical underpinning for the raison d'être of the WTO: the promotion of free trade. According to that theory, states should concentrate on producing what they are best at, to avoid generating opportunity costs and consequent economic inefficiency. States should produce and export those goods, and import other goods. The concurrent

* Sarah Joseph is a Professor of Law at Monash University, Victoria, Australia and is Director of the Castan Centre for Human Rights Law.

1 Marrakesh Agreement Establishing the World Trade Organization (15 April 1994) 1867 UNTS 3 [Marrakesh Agreement]. 
removal of trade barriers generates greater global economic efficiency, with all states providing to others the things that they are best at producing. Greater global efficiency should generate greater global wealth.

Greater global wealth in turn should alleviate poverty and enhance the ability of states to implement human rights, especially economic, social and cultural rights like the right to an adequate standard of living, or the right to an adequate standard of health care. ${ }^{2}$ Wealth generation should assist in promoting economic development, an important aspect of the right to development recognised in the Declaration of the Right to Development $1986 .{ }^{3}$ The alleviation of poverty itself may be characterised as the remedying of human rights abuse. ${ }^{4}$

Nevertheless, social justice and human rights concerns regarding the WTO are real and substantial. In Part II, I address concerns regarding an apparent democratic deficit within the WTO, whereby the generation of its rules are impacted by a biased process. Procedural biases have led to substantive iniquities within WTO rules, some of which are addressed in Part III, which concerns the impact of WTO rules on poverty and development within developing states. Part IV concludes the paper. Throughout this paper, I will also comment specifically on ramifications for the Pacific Islands.

\section{DEMOCRATIC DEFICIT AND THE WORLD TRADE ORGANIZATION ${ }^{5}$}

\section{A Negotiating Process}

Even in democratic states, the peoples of GATT/WTO members are rarely well informed of the negotiating process within the WTO, despite its potential to have profound effects on their livelihoods. ${ }^{6}$ Those who are detrimentally affected by GATT/WTO rules rarely, if ever, have access

2 International Covenant on Economic, Social and Cultural Rights (16 December 1966) 993 UNTS 3, Arts 11 and 12 [ICESCR].

3 Declaration on the Right to Development, (4 December 1986) GA. Res. 41/128 UN GAOR, $41^{\text {st }}$ Session (Annex) UN doc. A/Res/41/128 1987.

4 See for example Thomas Pogge "Recognized and Violated: the Human Rights of the Global Poor" (2005) 18 Leiden Journal of International Law 717, characterizing poverty as a human rights abuse. At the least, poverty accompanies human rights abuses: Sigrun I Skogly "Is there a right not to be poor?" (2002) 2 Human Rights Law Review 59.

5 A fuller exposition of the ideas in this section will be published as Sarah Joseph "Democratic Deficit, Participation and the WTO" in Sarah Joseph, David Kinley and Jeff Waincymer (eds) The World Trade Organization and Human Rights: Interdisciplinary Perspectives (Edward Elgar, United Kingdom, forthcoming, 2009).

6 Julio Lacarte "Transparency, Public Debate and Participation by NGOs in the WTO: a WTO Perspective" (2004) 7 Journal of International Economic Law 683, 686. 
to procedures of redress after a state's accession. ${ }^{7}$ Having said that, Tonga's accession was delayed by 18 months to facilitate greater public consultation than had occurred while it worked out the particulars of its accession deal. ${ }^{8}$ While that process of consultation delayed Tonga's membership, it did not result in Tonga joining on substantively different terms than had been available 18 months earlier. Vanuatu, which was set to join the WTO in 2002 after concluding its Accession Protocol in 2001, backed away, and wants a substantive renegotiation of the terms of its accession, which may allow for greater public input if it should occur. ${ }^{9}$ No renegotiation has yet taken place, and there is no indication from the WTO that it will occur.

GATT and WTO agreements have historically been negotiated in closed sessions by government trade specialists. ${ }^{10}$ Other governmental personnel in, for example, the labour sector, have not been involved. Amongst non-government organisations (NGOs), commercial interests have been uniquely represented. ${ }^{11}$ As multinational corporations dominate world trade, the dismantling of trade barriers clearly enhances their interests. Given their undoubted global power, the WTO negotiation process may serve to unduly enhance that power. ${ }^{12}$ Furthermore, as the negotiation process is dominated by free trade and commercial values, such values are likely to be prioritised where they conflict with, or diverge from, other values, such as human rights and environmental interests. ${ }^{13}$

7 See generally "Analytical Study of the High Commissioner for Human Rights on the fundamental principle of participation and its application in the context of globalization" (23 December 2004) UN doc. E/CN.4/2005/41, para 27 [UNHCHR].

8 Oxfam "Another Failure: Oxfam calls for reform of unfair WTO accession process" www.oxfam.org.nz/news.asp?aid=1122 (accessed 26 March 2008).

9 Jane Kelsey "World Trade and Small Nations in the South Pacific Region" (2004-5) 14 Kansas Journal of Law and Public Policy 248, 267-269.

10 Lacarte, above n 6, 683; Daniel C Esty "The World Trade Organization's legitimacy crisis" (2002) 1 World Trade Review 7, 10-11.

11 Ilan Kapoor "Deliberative Democracy and the WTO" (2004) 11 Review of International Political Economy 522, 530.

12 Jeffery Atik "Democratizing the WTO" (2000-2001) 33 George Washington International Law Review 451, 459; Robert O Keohane and Joseph S Nye Jr "The Club Model of Multilateral Co-operation and Problems of Democratic Legitimacy" John F Kennedy School of Government: Visions of Governance in the $21^{\text {st }}$ Century Working Paper 4, 5 www.ksg.harvard.edu. See UNCTAD World Investment Report 2002 Transnational Corporations and Export Competitiveness UNCTAD/WIR/2002 (United Nations, Geneva, 2002) 153, stating that two-thirds of world trade in the late 1990s was conducted by MNCs, including trade within MNCs.

13 Esty, above n 10, 13. 
Developing states are disadvantaged in negotiating WTO deals. They often lack clout and necessary technical expertise as well as the ability to constantly monitor WTO developments. ${ }^{14}$ Indeed, as discussed in Part III, current WTO rules are biased against developing states. For example, no Pacific Island member or observer had an office at the WTO in Geneva until 2004, when an office of the South Pacific Forum opened. ${ }^{15}$ Inadequate representation and participation by developing states in WTO processes means that substantive outcomes are less likely to reflect their interests. ${ }^{16}$ While technical assistance is offered by the WTO to improve the participation capacity of developing states through, for example, the Integrated Framework for Trade-Related Technical Assistance to Least Developed Countries, ${ }^{17}$ this assistance has not bridged the vast gap between the capacities of the poorest states and the richest states.

Negotiation processes have improved. For example, the notorious "Green Room" negotiations in which the most powerful states had once negotiated deals and presented them to the other members as fait accompli, have evolved so as to be more transparent and less determinative of outcomes. ${ }^{18}$ Indeed, it is clear in the current Doha round of negotiations that developing states are standing their ground more than they did during the Uruguay round. ${ }^{19}$ However, the Doha round continues to stall, while the status quo represented by the Uruguay negotiated rules, continue to favour developed states, as discussed in Part III. Furthermore, while developing state powers such as Brazil and India have accrued greater negotiating muscle, the same cannot be said for states such as Pacific Island states and others with small, vulnerable economies. The Pacific Island WTO members have pressed for the recognition of a new grouping within the WTO of "Small Vulnerable States". Such a grouping was not created in the latest Ministerial Declaration of Hong Kong, ${ }^{20}$ though there was a commitment to integrate such states more fully into the global trading system. Of course,

14 See for example J Michael Finger and Philip Schuler "Implementation of Uruguay Round Commitments: the Development Challenge" World Bank Policy Research Working Paper no. 2215 (September 1999) 3; UNHCHR, above n 7, 13. See also Kapoor, above n 11, 529.

15 Kelsey, above n 9, 261-263. This office is funded by the European Union.

16 UNHCHR, above n 7, 33-34.

17 Integrated Framework for Trade-Related Technical Assistance to Least Developed Countries WTO Doc WT/MIN (96)/14 (7 January 1997).

18 See Amrita Narlikar The World Trade Organization: A Very Short Introduction (Oxford University Press, Oxford, 2005) 16-17 and 146; UNHCHR, above n 7, 13.

19 Keohane and Nye, above n 12, 9. Indeed, Doha round talks collapsed in Geneva on 29 July 2008: one of the key reasons for the collapse were intractable disagreements between India and the United States over special safeguard measures for farmers in developing states: see Bridges Daily Update, Issue 10 (30 July 2008) available at http://ictsd.net (accessed 30 July 2008).

20 Hong Kong Declaration (18 December 2005) WT/MIN(05)/W/3/Rev.2 para 21. 
compliance with this vague promise, contained in the Doha Ministerial Declaration of $2001,^{21}$ is extremely difficult to ascertain, and it has arguably remained unfulfilled.

Systemic disadvantages within the negotiating culture of the WTO are of special concern, as the final rules are essentially framed by the negotiated outcomes. All WTO members are expected to adhere to the entire "package deal" arising from negotiations. ${ }^{22}$ Reservations, ${ }^{23}$ delayed ratification, or even non-ratification, are not recognised as legitimate options for WTO members. It is not presently expected that such options will be made available in new negotiations.

The negotiating disadvantage for acceding states, particularly small developing nations such as Vanuatu, Tonga and Samoa, in negotiating to join the WTO, are worse that those experienced by developing states during the Uruguay Round. As noted below, acceding states have generally been required to accept more onerous undertakings than existing members, without reciprocal guarantees. Existing WTO members have a right of veto to hold as a bargaining chip. While a weaker member might be bullied or otherwise persuaded to abstain from its use, an acceding member, particularly one with a weak economy, has few if any bargaining chips at all. An acceding state will also have comparatively little negotiating experience in the WTO milieu, and will find itself pitted against experienced trade negotiators from major economic powers, who are largely concerned with extracting the best deal possible for their own country or with establishing favourable negotiating precedents for the future, rather than with the development needs of the acceding state. ${ }^{24}$

\section{B Dispute Settlement Process}

The WTO's Dispute Settlement System (DSS) is a very powerful international dispute system; there is a remarkable level of compliance with its findings. A member who wins a dispute may impose economic countermeasures against the defeated member if the latter fails to comply with the ruling. This threat of economic punishment seems to motivate greater compliance than the threat of international censure, the only "punishment" that generally arises in the case of disobedience of the rulings of other international bodies, such as the International Court of Justice.

21 Doha Ministerial Declaration (20 November 2001) WT/MIN(01)/DEC/1 para 35.

22 There are two multilateral deals, which only bind states that voluntarily ratify them, concerning civil aircraft and government procurement; two further deals have now expired. There are also some flexibilities in the main WTO deals, such as the ability of states to choose which services they will liberalise under the General Agreement on Trade in Services (15 April 1994) 1869 UNTS 183 [GATS].

23 Some WTO treaties explicitly allow for reservations so long as all other parties consent to those reservations. This author is unaware of any reservations to WTO treaties.

24 See Oxfam New Zealand Submission to the Ministry of Foreign Affairs on the WTO accession negotiations of Samoa www.oxfam.org.nz/imgs/whatwedo/mtf (18 March 2008) 5-6 which notes the disparity of power between the Samoan negotiators and those from New Zealand. 
There are a number of concerns over aspects of the decision-making process within the DSS. Hearings within the DSS are closed to the public unless all parties consent. Decisions are made at first instance by trade experts, which can again lead to the subordination of non-trade interests to trade interests. ${ }^{25}$ Even so, international law outside the subject matter of trade is not ignored in the decision-making process. International customary law is relevant to the application of WTO norms ${ }^{26}$ but customary norms will not displace WTO norms unless they classify as jus cogens norms. ${ }^{27}$ Non-WTO treaties may be taken into account in interpreting WTO agreements, ${ }^{28}$ but Panels do not have to do so unless all WTO members are party to a particular treaty. ${ }^{29}$ Therefore, non-trade rules may have only a minor role, or may even have no role, in the determination of a dispute, regardless of the dispute's non-trade impact. ${ }^{30}$

As with the negotiating process, private commercial interests have been uniquely represented in dispute settlements. While only members have standing to initiate dispute settlement proceedings, private companies have propelled the initiation of numerous cases. ${ }^{31}$ For example, the dispute between the United States and Japan regarding Japan's treatment of imported film paper is more commonly known as the Kodak/Fuji case, which reflects the private interests that drove that litigation. ${ }^{32}$ The participation of other NGOs is far less influential. Panels may accept amicus briefs from third party private organisations, such as civil society organisations. ${ }^{33}$ However, there is no

25 See also Robert Howse "From Politics to Technocracy - and back again: the Fate of the Multilateral Trading Regime" (2002) 96 American Journal of International Law 94, 110; David M Driesen "What is Free Trade? The Real Issue Lurking behind the Trade and Environment Debate" (2001) 41 Virginia Journal of International Law 279, 313-314.

26 Korea - Measures Affecting Government Procurement (19 June 2000) WT/DS163/R para 7.96.

27 See European Communities - Measures concerning Meat and Meat Products (Hormones) WT/DS48/AB/R (16 January 1998) paras 120-125.

28 United States - Import Prohibition of Certain Shrimp and Shrimp Products (Shrimp Turtle case), WT/DS58/AB/R (12 October 1998) paras 126-134.

29 European Communities - Measures Affecting the Approval and Marketing of Biotech Products WT/DS291293/R (29 September 2006) para 7.68. Such unanimous membership of another treaty is virtually impossible, as the WTO permits the membership of certain non-states, such as Hong Kong, Chinese Taipei, and the European Communities, who are unable to ratify most other treaties.

30 See also, generally, Margaret Young "The WTO's Use of Relevant Rules of International Law: an Analysis of the Biotech Case" (2007) 56 ICLQ 907.

31 See Jeffrey Dunoff "The misguided debate over NGO participation at the WTO" (1998) 1 Journal of International Economic Law 433, 439-440 and 441-451. See also Keohane and Nye, above n 12, 23.

32 Dunoff, above n 31, 441-448. See Japan - Measures Affecting Consumer Photographic Film and Paper WT/DS44/R (31 March 1998). See also Gregory Shaffer Defending Interests: Public Private Partnerships in WTO Litigation (Brookings Institution Press, Washington DC, 2003).

33 The Appellate Body first allowed the admission of such material in the Shrimp Turtle case, above n 28, para 110. 
obligation to accept such briefs, nor do they necessarily take account of them in rendering decisions. ${ }^{34}$

Developed nations again have significant advantages within the DSS. The economic countermeasures imposed by developed against developing countries can have a devastating effect, but the same is rarely true in the reverse situation. ${ }^{35}$ The process of mounting a case before the WTO also requires monetary resources and technical knowledge, which developing states may lack. ${ }^{36}$ Of the Pacific Island member states, Fiji has been involved as a third party in three disputes involving export subsidies on sugar, ${ }^{37}$ while the other three nations have had, at the time of writing, no involvement in the dispute settlement processes. It is perhaps a good sign that no state has seen fit to bring a complaint against the Pacific Island states. On the other hand, their lack of engagement with the process may indicate that it is largely inaccessible due to a relevant lack of expertise or resources.

\section{Democratic Deficits and Human Rights}

Despite improvements in WTO processes, they remain biased in favour of interests of exporters and those of developed nations. ${ }^{38}$ This jeopardises, respectively, non-trade interests (including human rights) and the interests of developing nations if they should conflict with those aforementioned interests, especially given the disproportionate strength of the WTO regime compared to other global regimes. Article 25 of the International Covenant on Civil and Political Rights (ICCPR) ${ }^{39}$ guarantees the right to political participation, and has been interpreted to incorporate rights to participate in "all aspects of public administration, and the formulation of policy at the international, national, regional and local levels". ${ }^{40}$ Meaningful political participation

34 Nathalie Bernasconi-Osterwalder "Democratizing International Dispute Settlement: the Case of Trade and Investment Disputes" www.ciel.org/Publications/ICNRD6_300ct06.pdf (accessed 2 October 2007) 3-4. See also Joost Pauwelyn "The Sutherland Report: A Missed Opportunity for Genuine Debate on Trade, Globalization and Reforming the WTO" (2005) 8 Journal of International Economic Law 329, 346.

35 The compliance rate of poor countries with WTO decisions is better than that of rich countries: Sharyn O'Halloran "US Implementation of WTO Decisions" Presentation at Columbia University, WTO at Ten: Governance, Dispute Settlement and Developing Countries (6 April 2006) (paper on file with the author).

36 Shaffer, above n 32, 161-162.

37 See "Fiji and the WTO" www.wto.org/english/thewto_e/countries_e/fiji_e.htm (accessed 26 March 2008).

38 Pauwelyn, above n 34, 331-332.

39 International Covenant on Civil and Political Rights (16 December 1966) 999 UNTS 171 [ICCPR].

40 ICCPR, above n 39, General Comment 25: The right to participate in public affairs, voting rights and the right of equal access to public service (12 July 1996) ICCPR/C/21/Rev.1/Add.7 para 5 (emphasis added). A similar right has been recognised under the Convention on the Elimination of Discrimination against Women 1979: CEDAW General Recommendation 23: Political and Public Life (Sixteenth session, 1997) UN Doc. A/52/38/Rev.1, 61 (1997) para 39 (emphasis added). 
is also a key component of the right to development in Article 1 of the Declaration on the Right to Development. Participatory rights therefore apply at a global level, though the scope of the global aspect of the right is underdeveloped. ${ }^{41}$

The Human Rights Committee (HRC), the body created to monitor the implementation of the ICCPR, has conceded that Article 25 is satisfied if citizens indirectly participate in public affairs through elected representatives. ${ }^{42}$ Arguably, citizens (at least in democratic states) participate in WTO processes through trade representatives appointed by their elected governments. Participatory rights must also be enjoyed on a non-discriminatory basis, in accordance with rights of nondiscrimination. ${ }^{43}$ The limited range of interests represented by WTO negotiators and the disproportionate influence of business groups, coupled with the general lack of input by historically marginalised groups such as the poor, women ${ }^{44}$ and indigenous peoples, ${ }^{45}$ all raise questions regarding the adequacy of the level of indirect participation in WTO negotiations and decisionmaking.

Inadequate processes are likely to generate unsatisfactory substantive outcomes, which could undermine the enjoyment of other human rights. Therefore, I turn now to examine the substance of particular WTO rules in areas of relevance to developing states, such as the Pacific Island nations.

\section{WTO RULES, FREE TRADE AND DEVELOPING STATES}

Current WTO rules, as reflected in the Marrakesh Agreement, are biased against developing states. ${ }^{46}$ Indeed, this unsatisfactory situation was recognised by the Director-General of the WTO, Pascal Lamy, in 2006. ${ }^{47}$ Developing states undertook proportionately more obligations to liberalise their economies than developed states. While developed states generally have lower tariff bindings,

41 UNHCHR, above n 7,18.

42 Sarah Joseph, Jenny Schultz and Melissa Castan The International Covenant on Civil and Political Rights: Cases, Materials and Commentary (2 ed, Oxford University Press, Oxford, 2004) 657.

43 General Comment No 25, above n 40, para 6. Rights of non-discrimination are contained in ICCPR arts 2(1), 3, 25 and 26.

44 See Sara Dillon "A Farewell to 'Linkage': International Trade Law and Global Sustainability Indicators" (2002) 51 Rutgers Law Review 87, 103, 114, and 146-148, commenting on the general absence of women in the international trade field. See also Shelley Wright "Women and the Global Economic Order: a Feminist Perspective" (1995) 10 American University International Law Review 861.

45 UNHCHR, above n 7, 9.

46 Sarah Joseph "Trade to Live and Live to Trade" in M Baderin and R McCorquodale (eds) Economic, Social and Cultural Rights in Action (Oxford University Press, Oxford, 2006) 393-400. See also Kapoor, above n $11,527$.

47 Pascal Lamy "It's Time for a new 'Geneva Consensus' on making trade work for development" available at www.wto.org/english/news_e/sppl_e/sppl45_e.htm (accessed 30 October 2006) 3-4. 
the tariff cuts for developing states mandated in the Uruguay round were deeper. ${ }^{48}$ Indeed, many developing states were forced to maintain tariff levels lower than those to which they are committed under the WTO due to loan conditions imposed by other institutions, such as the World Bank and the International Monetary Fund. ${ }^{49}$ For example, Vanuatu severely cut tariffs due to pressure from the Asia Development Bank from the mid-1990s, even though it has not yet joined the WTO. ${ }^{50}$ These external pressures from international financial institutions, which pertain only to developing states as they are the only clients of such institutions, are not taken into account in WTO negotiations.

The General Agreement on Trade in Services (GATS) ${ }^{51}$ was a new agreement introduced in the Marrakesh Agreement. The most prominent human rights concerns with GATS have been that liberalisation in essential services, such as the provision of water and other utilities, health care, or education, could restrict the ability of states to subsidise and regulate the supply of such services, which could in turn deny the poor access to the essential services, such as the provision of water and education, that they need in order to enjoy economic social and cultural rights. This issue is of greater concern for developing states, where there is more poverty and less capacity to provide protection of economic and social rights. ${ }^{52}$

Furthermore, greater liberalisation has arisen regarding the types of services where developed states have a comparative advantage than comparable services for the developing states. ${ }^{53}$ While there has been considerable progress regarding liberalisation in financial and telecommunications

48 Finger and Schuler, above n 14, 6.

49 Joel R Paul "Do International Trade Institutions Contribute to Economic Growth and Development?" (2003) 44 Virginia Journal of International Law 285, 319; Oxfam Rigged Rules and Double Standards (Oxfam, London, 2002) 235; Dillon, above n 44, 95 and 150-151.

50 Oxfam New Zealand Discussion Paper "Proposed WTO Accession: Key Issues for Tonga" (7 November 2005) www.oxfam.org.nz/ (accessed 18 March 2008) 14. See also "Recommendations to Pacific Islands of the World Bank" in Ron Duncan et al Embarking on a Global Voyage: Trade Liberalisation and Complementary Reforms in the Pacific World Bank Reports 24417 - EAP (10 September 2002).

51 General Agreement on Trade in Services [GATS], above n 22.

52 See generally High Commissioner on Human Rights Liberalization of Trade in Services and Human Rights Report of the High Commissioner on Human Rights to the Economic and Social Council (25 June 2002) UN Doc E/CN.4/Sub.2/2002/9 paras 51-67.

53 See United Nations Development Programme [UNDP] Human Development Report 2005: International Co-operation at a Crossroads: Aid, Trade and Security in an Unequal World http://hdr.undp.org/en/reports/global/hdr2005 (accessed 25 November 2007) 136-138; Joel Trachtman "Legal Aspects of a Poverty Agenda at the WTO: Trade Law and 'Global Apartheid"' (2003) 6 Journal of International Economic Law 3, 14; Oxfam, above n 49, 226. 
services, ${ }^{54}$ there has been little progress regarding the opening of markets to mobile temporary labour forces, where developing states have a comparative advantage. ${ }^{55}$

Developing states faced greater transitional costs in properly implementing the various WTO agreements. ${ }^{56}$ For Tonga, Samoa and Vanuatu (if the latter two join the WTO), these costs will add to costs incurred during the time-consuming and painstaking accession process. For example, Vanuatu reported that its accession process cost US\$150,000 in administration and travel. Observer status costs US $\$ 20,000$ per year. By 2003 , it owed the WTO US $\$ 170,000$, which amounted to the entire annual budget of its Department of Trade. ${ }^{57}$

Finally, developing states conceded the creation of the Agreement on Trade Related Aspects of Intellectual Property Rights (TRIPS), ${ }^{58}$ which requires WTO members to protect intellectual property rights. Most intellectual property rights are held in the developed world, and they have maintained their comparative advantage in technological innovation. ${ }^{59}$ TRIPS has therefore led to a regressive transfer of wealth from the developing world to the developed world. ${ }^{60}$ The poor in the developing world have no capacity to exploit intellectual property rights, and cannot afford the price increases generated by the monopoly rights mandated by TRIPS. Higher prices obstruct access to goods which are essential for the enjoyment of human rights, such as life-saving medicines. ${ }^{61}$

The main concessions by developed states in the Marrakesh Agreement were to accede to the Agreement on Agriculture ${ }^{62}$ and the Agreement on Textiles and Clothing, ${ }^{63}$ which addressed trade

54 It must be noted that India is now having significant success in providing telecommunications services for offshore investors.

55 Narlikar, above n 18, 78-80. See generally Dipankar Dey "Movement of Natural Persons (Mode 4) under GATS: Advantage Developing Countries" Social Science Research Network (5 December 2006) available at http://papers.ssrn.com/sol3/papers.cfm?abstract_id=949435.

56 Finger and Schuler, above n 14, 1.

57 Kelsey, above n 9, 265 (see also n 119).

58 Agreement on Trade Related Aspects of Intellectual Property Rights (15 April 1994) 1869 UNTS 332 [TRIPS].

59 Jeffrey L Dunoff "The Death of the Trade Regime" (1999) European Journal of International Law 733, 748.

60 See UNDP, above n 53, 135. See also Deborah Z Cass The Constitutionalization of the World Trade Organization (Oxford University Press, New York, 2005) 229.

61 Such medicines are essential for the enjoyment of the rights to life (ICCPR art 6) and an adequate standard of health care (ICESCR art 12). Some TRIPS relief for the poorest states regarding access to pharmaceuticals for at least some diseases was negotiated pursuant to the Doha Declaration on the TRIPS Agreement and Public Health WT/MIN/01/DEC/W/2 (14 November 2001). See Amendment of the TRIPS Agreement: Decision of 6 December 2005, WTO Doc WT/L/641 (Decision of the General Council).

62 Agreement on Agriculture (15 April 1994) 1867 UNTS 410.

63 www.wto.org/english/docs_e/legal_e/16-tex.pdf. 
issues of particular significance to developing states. However, both Agreements allow for massive protectionism. ${ }^{64}$ Indeed, it was estimated in 2005 that developed states imposed tariffs on goods from developing states that were on average three to four times higher than those imposed on goods from other developed states. ${ }^{65}$

The special development needs of developing states are recognised in WTO provisions allowing for "special and differential treatment" (SDT). For example, developed states may offer preferential market access to developing states under the Generalised System of Preferences (GSP). ${ }^{66}$ Developing states were given more time to implement certain WTO agreements, though most of those longer timelines have now expired. Finally, "trade aid" should be provided to developing states by developed states. However, the most important SDT provisions are only exhortatory rather than binding: developed states do not have to offer trade aid nor do they have to offer preferential market access to developing states. ${ }^{67}$ As Professor Thomas Cottier has noted, SDT provisions have had little impact on addressing the "real needs" of developing states. ${ }^{68}$

Finally, the accession processes ${ }^{69}$ are of special concern to the many Pacific Islands that were not WTO members at the time of its creation (including those who are still not members). The accession process itself is extremely onerous, as the prospective new member must essentially satisfy each of the members of a working party established for its accession: any WTO member can join such a working party. ${ }^{70}$ Incumbent members have exploited accession processes to impose onerous conditions on acceding members, which they do not need to reciprocate. ${ }^{71}$ Furthermore, these conditions can set precedents for future members, who may face even more onerous

64 Lamy, above n 47, 3; Narlikar, above n 18, 26; Jordana Hunter "Broken Promises: Agriculture and Development in the WTO" (2003) 4 Melbourne International Law Journal 299; Christine Breining-Kaufman "The Right to Food and Trade in Agriculture" in Thomas Cottier, Joost Pauwelyn and Elizabeth Bürgi (eds) Human Rights and International Trade (Oxford University Press, Oxford, 2005) 358.

65 UNDP, above n 53, 127.

66 See "Differential and More Favourable Treatment, Reciprocity and Fuller Participation of Developing Countries" L/4903 GATT BISD 26S/203 (28 November 1979) known as the "Enabling Clause". The Enabling Clause formalised within the WTO the Generalised System of Preferences developed under the United Nations Conference on Trade and Development [UNCTAD].

67 Finger and Schuler, above n 14, 5; Gillian Moon "The WTO-Minus Strategy: Development and Human Rights under WTO Law" (2008) Human Rights and International Legal Discourse forthcoming, 16.

68 Thomas Cottier "From Progressive Liberalization to Progressive Regulation" (2006) 9 Journal of International Economic Law 779, 788.

69 See Marrakesh Agreement, above n 1, Article XII.

70 Kelsey, above n 9, 265.

71 UNDP Asia Pacific Human Development Report 2006: Trade on Human Terms (UNDP, Colombo, 2006) 131. 
requirements. For example, Oxfam has suggested that the proposed conditions for Samoa are worse than the "bad deal" received by Cambodia, which acceded in $2004 .{ }^{72}$ The precedent value of accession deals also explains why harsh requirements are extracted from small vulnerable economies such as those in the Pacific Islands by states, such as the United States, that hardly trade with them: those precedents are perceived as valuable for future negotiations with states with significant economies such as Russia. ${ }^{73}$

Conditions for new members can include additional obligations, not imposed under existing WTO rules ("WTO+" conditions), as well as a loss of concessions that a State would normally be entitled to under WTO rules ("WTO-" conditions). ${ }^{74}$ As an example of a WTO+ requirement, Tonga had to commit to liberalising a large number of services, even though GATS permits states to choose which services they will open up to foreign competition. ${ }^{75}$ Under Vanuatu's Accession Protocol, it committed to opening up "over four times the average number of sub-sectors for LDC Members at the time." 76 Tonga has an average tariff binding of 35 per cent, which is much lower than most comparable developing states. ${ }^{77}$

Regarding WTO conditions, Tonga became fully bound by TRIPS as of 1 January 2008, so there was virtually no delay in full implementation, even though all developing states benefited from timelines to facilitate implementation in the original Marrakesh Agreement. Vanuatu's Accession Protocol commits it to comply fully with TRIPS within two years, and to waive transitional periods for the Agreement of Trade Related Investment Measures (TRIMS). ${ }^{78}$ Vanuatu is a designated "Least Developed Country" (LDC). Regarding TRIPS, LDCs do not have to guarantee patent protection on drugs until 2016. ${ }^{79}$ Regarding TRIMS, the transitional period for TRIMS for LDCs was extended under the Hong Kong Ministerial Declaration for a period of seven years. ${ }^{80}$ It is not however clear whether Vanuatu, despite its LDC status, will benefit from either rule under the terms of its Accession Protocol.

72 Oxfam New Zealand Submission to Ministry of Foreign Affairs on the WTO accession negotiations of Samoa www.oxfam.org.nz/imgs/whatwedo/mtf (accessed 18 March 2008) 10.

73 Kelsey, above n 9, 274

74 UNDP, above n 71, 131.

75 Kelsey, above n 9, 271; see also Oxfam New Zealand Discussion Paper, above n 50, 8-11.

76 Kelsey, above n 9, 267

77 Oxfam New Zealand Discussion Paper, above n 50, 13.

78 Agreement of Trade Related Investment Measures (15 April 1994) 1869 UNTS 299 [TRIMS]. See Kelsey, above n 9, 267.

79 See Doha Declaration on TRIPS and Public Health 2001, above n 61, para 7.

80 Hong Kong Declaration, Annex F, para 84. 
The General Council of the WTO ${ }^{81}$ issued a decision in early 2003 on the Accession of LeastDeveloped Countries in which it urged WTO members to "exercise restraint in seeking concessions and commitments on trade in goods and services from acceding LDCs". ${ }^{82}$ The General Council also stated that SDT, including special transitional arrangements for LDCs, should be made available to any acceding LDC. ${ }^{83}$ This decision however has proven to be an empty promise: in 2004 Samoa reported that "nothing had changed". ${ }^{84}$

The above analysis demonstrates that current WTO rules are unfair to developing states. However, aside from issues regarding inequity in current rules, a further question arises: is the reduction of barriers to trade likely to alleviate poverty ${ }^{85}$ The effect of free trade on economic growth is often presumed. ${ }^{86}$ However, global statistics are unclear on this issue. A 2005 report by the World Bank concedes that the correlation between trade liberalisation and economic growth is inconclusive. ${ }^{87}$ The evidence of the effect of free trade on poverty alleviation is also unclear. There has not been a huge or consistent reduction in absolute poverty. ${ }^{88}$ However, freer trade has apparently accompanied greater inequality both between and within states, ${ }^{89}$ though it is uncertain

81 The General Council consists of all WTO members.

82 General Council "Accession of Least-Developed Countries" WT/L/508, 20 January 2003, section I.

83 Ibid, section II.

84 Kelsey, above n 9, 266 (note 132).

85 See further, Joseph, above n 46, 400-409.

86 See Robert Howse "Mainstreaming the Right to Development in International Trade Law and Policy at the World Trade Organization" UN Doc E/CN.4/Sub.2/2004/17 (9 June 2004) paras 15 and 29, criticising this "neo-liberal article of faith".

87 World Bank Economic Growth in the 1990s: Learning from a Decade of Reform (World Bank, Washington DC, 2005) www1.worldbank.org/; see also UNDP, above n 53, 119.

88 UN Commission on the Private Sector and Development [CPSD] Unleashing Entrepreneurship: Making Business work for the Poor www.undp.org/cdsd/report (accessed 23 November 2005) 6.

89 See United Nations Report on the World Social Situation 2005 (Department of Economic and Social Affairs, 2005); Paul, above n 49, 310; Chantal Thomas "Poverty Reduction, Trade, and Rights" (2003) 18 American University International Law Review 1399, 1402-3; Oxfam, above n 49, 67-68; Working Group on the Right to Development "Review of Progress and Obstacles in the Promotion, Implementation, Operationalization, and Enjoyment of the Right to Development" UN Doc E/CN.4/2004/WG.18/2 (17 February 2004) paras 12-18. Compare with World Bank World Development Report 2006 where it is argued that international inequality has slightly decreased in the last twenty years. The report nevertheless concedes "global inequalities are massive". 
whether that inequality has been caused by globalisation. ${ }^{90}$ Extreme inequality breeds resentment, and is socially unsustainable. ${ }^{91}$

Premature liberalisation is counterproductive and even disastrous in some circumstances. The dismantling of trade barriers inevitably destroys certain local industries. The consequent social dislocation of affected workers causes significant detriment to their economic and social rights, such as the right to work and to an adequate standard of living. ${ }^{92}$ Poorer states are often unable to provide for any alternative work or compensation for such workers. The World Bank, despite its enthusiastic support for economic liberalism in the Pacific Islands, has conceded that Pacific industries could suffer hugely with increased competition, while the birth of new industries might take time. ${ }^{93}$

The reduction of tariffs in developing states is problematic. In the Pacific Island States, tariffs constitute twenty to fifty per cent of government revenues. ${ }^{94}$ Tariffs are relatively simple to collect: many developing states lack the infrastructure to properly police collection of other taxes, such as consumption taxes or income taxes. ${ }^{95}$ The International Monetary Fund has estimated that less than thirty per cent of lost tariff revenue has been recovered by developing states through other means in the last twenty-five years. ${ }^{96}$

Furthermore, a state is a vulnerable player in the world economy if its comparative advantage lies essentially in agriculture or unskilled labour, as is the case with many developing states, including island states in the Pacific. ${ }^{97}$ Agricultural markets are notoriously unstable, and often generate very low returns for producers. ${ }^{98}$ Workers in the low-skilled manufacturing sector can be

90 The WTO and ILO note that technological change is a possible alternative driver of inequality, in WTO and ILO Trade and Employment: Challenges for Policy Research (Geneva, 2007) 39.

91 Paul, above n 49, 320; Oxfam, above n 49, 23. See also Amy Chua World on Fire (Anchor, New York, 2004).

92 See Pranab Bardhan "Does Globalization Help or Harm the Poor?" (April 2006) Scientific American 68, 72.

93 Kelsey, above n 9, 253 reporting on World Bank recommendations.

94 Ibid, 271; see also Oxfam New Zealand Discussion Paper, above n 50, 13-14.

95 See Lorand Bartels "Trade and Human Rights" in Bethlehem, McRae, Neufeld and Van Damme (eds) Oxford Handbook of International Trade (Oxford University Press, Oxford, 2008) 9. See also Kelsey, above n 9, 281, on the political difficulties in Tonga replacing its $\$ 6$ million tariff revenue with other taxes.

96 Baunsgaard and Keen Trade Revenue and Trade Liberalisation (2005) IMF Working Paper WP/05/112.

97 Kelsey, above n 9, 256, on the economy of Vanuatu, and at 259, on the economies of Fiji, Papua New Guinea and the Solomon Islands.

98 See UNDP, above n 53, 139-142; Paul, above n 49, 315; Carmen C Gonzalez "Symposium: Whither goes Cuba? Prospects for Economic and Social Development: Trade Liberalization, Food Security, and the 
suddenly made redundant by the relocation of investments to countries with cheaper labour, or by technological changes. Such workers have little employment mobility, so job losses can cause severe economic hardship. ${ }^{99}$

States need to target and nurture niche industries to ensure the development of dynamic and sustainable comparative advantages, or they will probably remain poor. ${ }^{100}$ The industrial capacity of developed states and the South East Asian "tiger economies" were nurtured by protectionist policies prior to trade liberalisation. ${ }^{101}$ Many of the methods used successfully to foster development in such states, such as targeted protectionism, reverse engineering, and requirements for investors to source goods from local providers, are no longer permitted under the WTO. ${ }^{102}$ States should also develop infrastructure to cope with the inevitable social consequences of liberalisation, ${ }^{103}$ and to develop a skilled and productive workforce, so as to eventually be able to maximise their benefits from trade liberalisation. ${ }^{104}$

Therefore, a slow and sequenced approach to liberalisation in underdeveloped nations, so as to allow them to build the domestic economic and social platforms needed to cope with and reap the benefits of a liberal trade regime, is preferable to premature liberalisation. ${ }^{105}$ Such policy space is not however allowed under current WTO rules. ${ }^{106}$

Environment - The Neoliberal Threat to Sustainable Rural Development" (2004) Transnational Law and Contemporary Problems 419, 434; World Commission on the Social Dimension of Globalisation A Fair Globalization: Promoting Opportunities for all (ILO, Geneva, 2004) para 375.

99 Oxfam, above n 49, 40 and 82-83; Paul, above n 49, 315; Bob Hepple Labour Laws and Global Trade (Hart, Oxford, 2005) 17.

100 Rodrik The Global Governance of Trade: As if Development Really Mattered (UNDP, New York, 2001) 19; Oxfam, above n 49, 233; World Commission on the Social Dimension of Globalisation, above n 98, xiii.

101 Oxfam, above n 49, 26 and 147; World Commission on the Social Dimension of Globalisation, above n 98, 362; Thomas, above n 89, 1406. See also UNDP, above n 71, 146.

102 Michael H Davis and Dana Neacsu "Legitimacy, Globally: The Incoherence of Free Trade Practice, Global Economics, and the Governing Principles of Political Economy" (2001) 69 U of Missouri Kansas City L Rev 733, 777-778. See Kelsey, above n 9, 272, on the Tongan measures which assist agricultural producers, which are probably now illegal under its WTO obligations.

103 Paul, above n 49, 300. See also Oxfam, above n 49, 91 and Lamy, above n 47, 5.

104 Thomas, above n 89, 1408; Trachtman, above n 53, 18.

105 UNDP, above n 53, 135; Dani Rodrik "Trading in Illusions" Foreign Policy (March/April 2001) 55. See also Dani Rodrik "How to Save Globalisation from its Cheerleaders" (September 2007) www.ksghome.harvard.edu/ (accessed 23 November 2007) and Robert Driskill "Deconstructing the arguments for free trade" (February 2007) www.vanderbilt.edu/econ/faculty/Driskill/ DeconstructingfreetradeAug27a2007.pdf (accessed 25 November 2007) 15-16.

106 Rodrik, above n 105, 19; Oxfam, above n 49, 233. 


\section{CONCLUSION: A NEW DEAL?}

There are strong arguments in favour of a new asymmetric deal that redresses the procedural and substantive imbalances of the Marrakesh Agreement in favour of states with vulnerable economies, ${ }^{107}$ such as the Pacific Island members, incorporating for example the opening of agricultural markets by developed states and increased policy space for poorer states (such as TRIPS relief). While such a deal might seem politically unlikely, one may note that developed states would accrue some benefits from such a deal, such as goodwill for future trade negotiations (a far cry from the current gridlock) and cheaper goods for their consumers. ${ }^{108}$ Greater latitude for policies that promote "non-trade" issues such as human rights, labour standards, food safety, and environmental protection, when they impact on trade, should also be allowed. ${ }^{109}$ Again, such concessions would redress possible biased outcomes generated by biased processes, which disadvantage non-trade constituencies.

Such proposals of course might encourage states to lapse into protectionist strategies, undermining economic efficiency. Developing states could abuse their increased latitude, while all states could seek to defend protectionist laws by resort to excuses based on "non-trade" arguments. $^{110}$ However, world economic patterns have simply not conformed to orthodox theoretical expectations. ${ }^{111}$ It is legitimate to call for an approach that allows developing states to tailor economic strategies to their specific development needs, and allows states to be able to reasonably regulate to promote important "non-trade" agendas in areas of social justice. ${ }^{112}$ "Fear of protectionism" should not be treated as an end that trumps other interests.

The many Pacific Islands that are not yet parties to the WTO must be mindful of the dangers of premature liberalisation, as well as the unfairness of the negotiating process for acceding states. Membership of the WTO should not be bought at any price. It may be worthwhile to delay accession until the remaining large economies, such as Russia and Iran, have concluded their accession protocols. WTO members may be more willing to offer concessions to the Pacific Islands when they are confident that those concessions will not be expected by more powerful states.

107 Lamy, above n 47, 4. Such states go beyond the traditional "LDC" category, as many poor states, such as Tonga, fall outside that category. See "The Criteria for the Identification of LDCs" www.un.org/specialrep/ohrlls/ldc/ldc\%20criteria.htm where per capita income must be below US\$750.

108 Joseph, above n 46, 409-414.

109 See Rodrik, above n 105, 26-31.

110 Ibid, 19 and 26-27.

111 World Bank, above n 87; Rodrik, above n 105.

112 Rodrik, above n 105, 28-31. 
Finally, one may note that economic globalisation has been the subject of civil society campaigns across the world for over a decade. However, it is a relatively new topic in the Pacific. Pacific NGOs are not particularly well versed in the technicalities of economic globalisation and WTO law. There is an urgent need for greater expertise to provide an alternative voice for the ear of Pacific governments, who are being advised by powerful neighbour states as well as international institutions, such as the World Bank, the International Monetary Fund and Asia Development Bank to liberalise their economies and join the WTO. Pacific governments should at least be exposed to serious arguments that the price of membership may be too high. In that respect, the formation of the Pacific Network on Globalisation in 2001 was an important step towards greater informed dialogue on globalisation in the Pacific. ${ }^{113}$

113 See Claire Slatter "Treading Water in Rapids? Non-Governmental Organizations and Resistance to NeoLiberalism in Pacific Island States" in Stewart Firth (ed) Globalisation and Governance in the Pacific Islands (ANU E Press, Canberra, 2006) http://epress.anu.edu.au/ssgm/global_gov/ mobile_devices/ch02.html. For the Pacific Network on Globalisation, see www.pang.org.fj. 
